\title{
TEATRO E CRÔNICA DE D. JOÃO DA CÂMARA: ASPECTOS DA LITERATURA PORTUGUESA NA PASSAGEM DO SÉCULO XIX PARA O XX.
}

Rita de Cássia Lamino de Araújoํ.

RESUMO: Em Portugal, os autores da geração de 1890, da qual o cronista e dramaturgo D. João da Câmara faz parte, passaram a expressar em suas obras uma nova concepção do mundo produzindo obras simbolistas, que primavam pelo conteúdo espiritual e estético; obras neorromânticas lusitanistas e neogarrettistas, que apresentavam sentimento nacionalista traduzido no culto ao passado histórico glorioso e na exaltação do campo e da cultura popular campesina portuguesa. Em vista disso, este artigo propõe-se a apresentar considerações sobre as peças $O$ Pântano, O Beijo do Infante e Os Velhos, de D. João da Câmara, e as crônicas do autor, publicadas tanto em O Ocidente: revista ilustrada de Portugal e do Estrangeiro, quanto no jornal $A$ Gazeta de Notícias, de modo a observar como se manifestam essas novas tendências literárias finisseculares na obra desse autor.

PALAVRAS-CHAVE: D. João da Câmara, Simbolismo, Neorromantismo, Teatro, Crônica

\section{JOAO DA CAMARA'S DRAMA AND CHRONICLES: ASPECTS OF PORTUGUESE LITERATURE AT THE TURN OF THE 19TH AND THE 20"H CENTURIES}

\begin{abstract}
In Portugal, the authors of the 1890's generation, to which the columnist and playwright D. João da Câmara belonged, began to express a new worldview through Symbolist works which were distinguished for its aesthetic and spiritual content, Neo-Romanticist and NeoGarretian works which presented nationalist sentiments translated into the cult of the glorious historical past and the exaltation of the Portuguese countryside and peasant culture. In the light of that, this article intends to investigate $\mathrm{D}$. João da Câmara's plays $O$ Pântano, O Beijo do Infante, Os Velhos and his chronicles published in the magazine O Ocidente: revista ilustrada de Portugal e do Estrangeiro, as well as in the newspaper A Gazeta de Noticias in order to observe how the new literary tendencies at the time are present in the author's work.
\end{abstract}

Keywords: symbolism, Neo-romanticism, theater, chronic

\section{Introdução}

No século XIX, passada a euforia materialista científica, o homem, que acreditava na explicação e resolução de tudo por meio da ciência e da razão, descobre-se iludido diante de acontecimentos e questionamentos que ultrapassam a esfera do conhecimento empírico. Surge, então, o conflito entre a "carne e o espírito, a mesquinhez diária e as exigências interioristas" (PIMENTEL, 1981, p.140). Esse conflito desperta nos intelectuais o sentimento de tédio, desânimo, impotência e descrença, fazendo-os distanciar-se da sociedade, deixando de apresentar um esboço preciso do homem e do mundo para cultuar o vago, o subjetivo, em busca de sensações mais sutis, alheias às tensões históricas e sociais.

1 Aluna do Curso de Doutorado do Programa de Pós -Graduação, Literatura e Vida Social, da Faculdade de Ciências e Letras - Unesp - Assis. Bolsista Capes. 


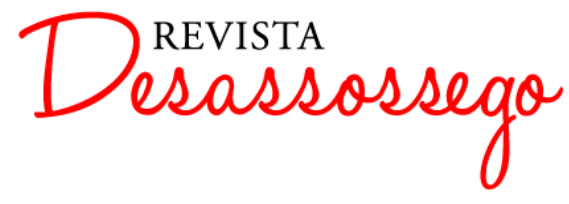

DESASSOSSEGO 12 | DEZ/2014 | ISSN 2175-3180

DOI: http://dx.doi.org/10.11606/issn.2175-3180.v6i12p81-94

Em Portugal, os autores da geração de 1890 passaram a expressar em suas obras essa nova concepção do mundo, produzindo textos simbolistas que primavam pelo conteúdo espiritual e estético; e obras neorromânticas lusitanistas e neogarrettistas, que apresentavam um sentimento nacionalista traduzido no culto do passado histórico glorioso e na exaltação do campo e da cultura popular campesina portuguesa. Em vista disso, este artigo propõe-se a apresentar considerações acerca das peças $O$ Pântano, O Beijo do Infante, Os Velhos e das crônicas de D. João da Câmara publicadas em O Ocidente: revista ilustrada de Portugal e do Estrangeiro e na Gazeta de Notícias, de modo a observar como essas novas estéticas aparecem na obra desse autor.

\section{A Estética Simbolista em $O$ Pântano e nas crônicas de D. João da Câmara}

No final do século XIX, surge um novo tipo de intelectual na França, que recebe o epíteto de decadente. Segundo Pimentel (1981, p.140), “o decadente, dando continuidade à linha iniciada pelos românticos, exprime a sua angústia, perplexidade e pessimismo numa rebeldia individualista, feroz e geradora de caótico desespero". Este homem, desiludido de si e da sociedade em que vive, aliena-se do mundo e despreza a vida em sociedade, procurando compensar a enfadonha vida cotidiana e seus males, voltando-se para si por meio do uso da intuição imprecisa, do culto do inconsciente e subconsciente e das forças misteriosas, defendendo a transcendência do espírito - visto que acreditava ser o homem regido por forças espirituais vindas das profundezas da alma.

Essa nova concepção do homem e da literatura introduziu-se em Portugal por meio das revistas acadêmicas coimbrãs Boêmia Nova e Os Insubmissos, liderada por Eugênio de Castro, João de Meneses e Francisco de Bastos, ambas de 1889, e se disseminou por meio de obras como Oaristos (1980), de Eugênio de Castro, Só (1892), de Antônio Nobre, As Cidade e as Serras (1901), de Eça de Queirós, entre outras. Nessas obras, os escritores demonstravam uma renúncia diante das vaidades das sociedades e a tentativa de representar o homem submerso num mundo de mistério, vítima de forças as quais não conseguia controlar e nem delas se defender. Surge dessas atitudes o sentimento de decadência que, de acordo com Ana Balakian (1967, p.59), consiste num "estado de espírito do poeta que está assombrado com a crueldade do tempo e eminência da morte". Esse sentimento se sobressai em algumas crônicas escritas por D. João da Câmara no jornal Gą̧eta de Notícias: "olhar pela janela do meu quarto entristece-me. Meia dúzia de árvores minhas amigas de pequeno envelheceram muito. Morreram algumas e deixaram entre as outras um vazio 
melancólico" (CÂMARA, 09 dez. 1901, p.1). Percebe-se que o autor lamenta tristemente a passagem do tempo que faz com que as pessoas e a própria natureza envelheçam e morram. O tempo, assim, é visto como uma força silenciosa e aterrorizadora que, de modo lamentável, direciona tudo irremediavelmente à melancolia e à morte.

Em outra crônica, o autor demonstra o seu esfacelamento diante do poder de certas forças desconhecidas que o envolvem numa atmosfera de tristeza e tédio, tornando-o melancólico, mesmo quando o seu desejo é viver e exaltar a beleza das coisas:

E quanto vou escrevendo é catilinária ao meu feitio d'ontem, a minha insônia de toda a noite, ao estado do meu espírito cansado de lutar contra fantasmas negros, cujo rosto não vejo. Se o dia está sendo alegre para tantos, que tem os meus pequeninos desgostos que se irritar, querem tomar posse de todo o meu ser, obrigar-me, num dia lindo como o de hoje, em vez de cantar o sol e as andorinhas, vir para aqui desabafar falando de melancolias? (CÂMARA, 31 ago. 1903, p.3)

Com efeito, esse sentimento melancólico e decadente presente nas crônicas, denunciador de uma atmosfera sombria e aniquiladora pertencente à estética simbolista/ decadentista foi, também, desenvolvido por D. Câmara na maioria das suas principais peças teatrais. Entre elas destaca-se O Pântano, encenada no ano de 1894, no teatro de D. Maria, sob a influência da peça La Princesse Maleine, do dramaturgo belga Maeterlinck.

O drama dividido em quatro atos consiste numa história de amor, traição e morte em que as personagens são condicionadas por forças obscuras, que ultrapassam a razão e as envolvem em uma nebulosa atmosfera carregada de presságios. Tudo se passa ao redor de Luísa, mulher de beleza misteriosa, fatal, que exerce grande poder de sedução sobre Alfredo, seu amante: "Pensa tu por mim, pensa, Luísa, pensa pelo escravo, que pôs debaixo dos teus pés toda uma alma ferida e que só vive de sentir-se morrer" (CÂMARA, 2006, p.324); e sobre o duque: "Luísa como é que na doçura do teu beijo penetrou no meu corpo este veneno que o percorre?” (CÂMARA, 2006, p.295), a quem seduz e o condiciona ao casamento e à morte, apenas pelo capricho de conquistar um título ilustre ao amante. A própria Luísa não consegue escapar das forças obscuras das quais, devido à sua ambição, sofre, vivendo em um local sombrio e lúgubre que a sufoca, como é possível depreender de sua conversa com o marido, que a levou para morar em seu palácio próximo ao pântano:

Eis-me agora aqui, estou num mundo estranho, fora do mundo em que vivia! Sinto o frio do medo a percorrer-me! Por que me trouxe? Eu bem sei que veneno aqui respiro, bem sei que miasmas sobem dessa charneca enorme, correm as salas do palácio, penetram-nos nas veias percorrem- 
nos os corpos, assassinando as almas. Pensou talvez em roubar-me a força de vontade, roubar-me o entendimento! (CÂMARA, 2006, p.294)

A ação da peça, com exceção do primeiro ato, ocorre em um velho e melancólico "palácio arruinado", parecido com um túmulo de paredes úmidas e corredores longos e sombrios por onde sopram os ventos aflitos por entre as fendas e se escutam tristes gemidos, velhos rezando, gargalhadas de loucos, o rumor da trovoada, os uivos de cão e corujas agourentas que voam em torno do palácio piando lugubremente, anunciando longas noites repletas de terríveis presságios: "a noite o que tem hoje? O nevoeiro do pântano parece que todo ele penetrou dentro de mim!" (CÂMARA, 2006, p.268).

Para a descrição do antigo palácio e da noite, o autor utiliza-se de diversas imagens que criam um ambiente mórbido, sombrio e fantasmagórico, carregado de espectros e presságios, bem ao estilo simbolista, e, por meio dela, atribui forma às forças misteriosas e maléficas que rondam e se impõem aos seres humanos. Essas forças são simbolizadas, principalmente, pelo pântano que existe próximo ao palácio e reflete o estado de espírito angustiado das personagens dominadas por desejos doentios e predestinadas a um destino inflexível e mortal, como é possível depreender da conversa entre o Duque e José:

DUQUE: (arrepiado) - Contágio horrível! Sinto a razão a fugir-me. Fecha-me essa janela. É fatídica a luz no poente ainda a espreitar entre os pinheiros. E conta lá, que vês? Que sabes? Este palácio é como um túmulo. Quero saber a vida dos fantasmas. Tu sabes? Conta.

JOSÉ: É a neblina desse pântano. Entra a umidade pelas fendas, voam na casa os pesadelos. (CÂMARA, 2006, p.307).

O modo como o pântano é representado no drama simboliza "o mundo onde se agita uma humanidade condenada; e os miasmas que dele se evolam representam as forças sobrenaturais que dirigem os homens para um destino fatal e inexorável." (REBELLO, 1994, p.305). Assim, o pântano se "alastrou", atingindo todos os que vivem à sua volta com sua podridão, desmoralizando as personagens contagiadas por uma atmosfera de ambição, insanidade, delinquência e morte diante de um destino condenado e aniquilador, do qual não se consegue desvincular.

Esse ambiente lúgubre e sufocante, repleto de miasma, espectros e presságios, ainda é fornecido mediante uso de imagens outonais que fazem com que a obra ganhe qualidade poética e com que o público sinta a angústia dos personagens e pressinta a presença do sobrenatural. Como exemplo do uso da imagem do outono no drama, tem-se a cena I do ato II, na qual José conversa com Matilde sobre a sua história de vida: 
As minhas histórias são cheias de tristeza como a noite que desce, como o Outono que desfolha as árvores, como a sua vida pobre menina! Se eu pudesse havia de contar-lhe uma história antiga, do tempo em que meus cabelos eram negros como o seus, de quando o sol, que eu bebia nesses campos, me alegrava como um vinho velho. Mas vão tão longe! Parece que não foram comigo. Não sei que sopro de peste um dia passou por esta casa. (CÂMARA, 2006, p.291).

José Carlos Seabra atenta para o fato de ocorrer no "outono e ao findar da tarde tudo o que de importante se nos depara na lírica decadentista" (SEABRA, 1975, p.351). Na passagem acima, essa estação representa a nostalgia de José perante um passado feliz suprimido por forças misteriosas que transformaram a felicidade do lugar em angústia.

Do mesmo modo, o uso da imagem do outono é evocada em algumas crônicas em que o autor rememora o passado tranquilo e feliz, em detrimento de um presente angustiante e opressor: "Em noites plácidas de luar, deste luar de outono tão sereno, ouvese de muito longe o sussurrar das fontes e os pinhais murmuram queixas muito brandas. [...] Foi de amores, é de saudade, foi de esperança, é de desconsolo." (CÂMARA, 10 nov. 1902, p.1). Na descrição, o outono representa o presente, período da vida após a juventude, repleto de sonhos e alegrias. No entanto, com a aproximação da velhice, as limitações e perdas que ela representa, resta apenas a lembrança saudosa, que desperta o sentimento melancólico no autor. Deste modo, enquanto no drama, D. João da Câmara demonstra um ambiente lúgubre e decadente representante da sociedade em que vive, nas crônicas, a estética simbolista evidencia-se por meio das descrições do seu estado de espírito diante da lembrança de um passado feliz perante o presente aniquilador.

\section{O Neorromantismo Lusitanista em $O$ Beijo do Infante e nas crônicas}

Junto à estética simbolista desenvolveu-se, em Portugal, no final do século XIX, uma literatura de base historicista e folclórica que primava pela valorização da "alma nacional", por meio do culto do passado histórico glorioso e da exaltação da cultura popular campesina portuguesa. A esse movimento literário calcado no nacionalismo, deu-se o nome de Neorromantismo Lusitanista. O desenvolvimento dessa corrente literária nacionalista e tradicionalista, na década de 1890, condiz com o sentimento doloroso de decadência que pairava sobre a nação portuguesa depois que o sonho de tornar-se novamente uma nação soberana, como fora no auge da exploração e colonização das possessões africanas, representada pelo mapa cor de rosa (1886), foi dissipado pelo Ultimato dado pela Inglaterra em 1890. Na tentativa de superar esse sentimento e reerguer 


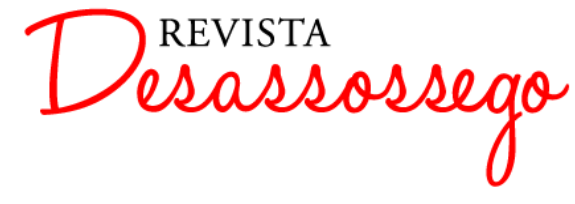

DESASSOSSEGO 12 | DEZ/2014 | ISSN 2175-3180

DOI: http://dx.doi.org/10.11606/issn.2175-3180.v6i12p81-94

a moral da nação, os escritores portugueses agarraram-se ao passado, numa atitude de glorificação e valorização das personalidades, acontecimentos e períodos históricos em que se sobressaía, de modo intenso, "as virtudes e as energias morais e espirituais da Raça" (AMORA , 1969, p.20), tais como: a consolidação da nação lusitana na Idade Média, a expansão marítima e colonização de novas terras, o Sebastianismo e a Restauração.

Essa manifestação histórica-nacional foi divulgada, principalmente, pelos dramas históricos. Esses agiam como uma espécie de compensação ao sentimento de agonia que pairava sobre o país, uma vez que conseguiam, por meio da fantasia teatral, reviver os importantes fatos históricos da nação, de modo a reavivar o estado de espírito e a moral do povo português diante de um presente arruinado e distante da civilização europeia; numa tentativa de prosperar em um futuro visto, na época, como incerto e nebuloso.

Um dos dramas históricos de D. João da Câmara que condiz com o interesse pelas colônias africanas da época e demonstra claramente a fé no passado como alavanca para o presente e futuro é Beijo do Infante. Apresentado no teatro de D. Amélia, em 21 de maio de 1898, é um dos únicos que exibe um momento glorioso da vida nacional: o da expansão e descobrimento marítimo. Isso se deve, primeiramente, ao fato da peça fazer parte do programa comemorativo do quarto centenário da viagem de Vasco da Gama à Índia, ocorrida durante os anos de 1487 e 1499, momento muito importante para a história portuguesa, uma vez que traçou a rota marítima para o Oriente, abrindo caminho para o desenvolvimento comercial das nações ocidentais. Ademais, sua representação coincide com um período de expectativas em que o país estava voltado para a política de exploração e administração das colônias africanas. Assim, "o Beijo do Infante representava um eco daquele interesse por assuntos relativos às colônias - e, ao mesmo tempo, uma fuga no passado, à humilhante realidade criada pelo Ultimato, ainda presente na memória nacional." (REBELLO, 1948, p.297)

A ação da peça se passa no ano de 1499, em um vilarejo próximo a Sagres. A jovem Teresica, sua avó, Marta, e seu tio avô, André, esperam a volta de Luís, neto de André, que partira com a esquadra de Vasco da Gama em 1497 em direção ao Oriente e só retornaria em 1499. As mulheres demonstram-se apreensivas com os riscos sofridos pelos marinheiros em alto mar e desesperançosas em relação à volta do jovem, enquanto que André mantinha fervorosa a esperança do regresso do neto. Enquanto o esperava, o velho marinheiro revivia momentos inesquecíveis do seu passado como integrante da armada de 
Bartolomeu Dias que, em 1488, dobrara o Cabo das Tormentas, depois denominado Cabo da Boa Esperança; e, principalmente, o dia memorável em que, ainda criança de colo, como lhe contava sua mãe, fora beijado na boca pelo Infante D. Henrique, grande incentivador dos empreendimentos marítimos portugueses:

Sabeis como D. Henrique era metido consigo e duro para os mais. Foi sol que lhe subiu à cabeça naquela manhã ou viu em mim pequenino as glórias do futuro? Se adivinhou que [...] eu havia de ir ao cabo dessa África e o meu neto... aonde? ... aonde, Teresica?... Talvez a essa Índia, que há tanto buscamos! [...] O infante ergueu-me em seus braços, afagou-me os canuditos loiros, beijou-me na minha boca! (CÂMARA, 2006, p.133)

O beijo dado pelo Infante em André aparece como uma alegoria neolusitanista, pois é tomado pelo marinheiro como um legado da predestinação da alma portuguesa para as grandes conquistas marítimas e, por isso, deve ser passado de geração para geração, de modo a manter o primado de Portugal como nação soberana: "Naquele beijo deu-me um pedaço da sua alma. [...] Esse pedaço de alma sinto-o, sinto-o a querer subir aos lábios para dar ao meu neto!...” (CÂMARA, 2006, p.133). Logo, a imagem do beijo dado pelo infante a André quando criança e o desejo do velho marinheiro de repassar esse beijo para o neto são simbólicos, pois mostram que o presente da nação portuguesa e a construção do seu futuro estão embasados no passado glorioso de Portugal.

A demora do regresso de Luís despertava na família sentimentos contraditórios que pareciam coincidir com os anseios que pairavam sobre o país no final do século XIX. De um lado, o velho marinheiro, André apresentava um pensamento condizente com o da aristocracia decaída e saudosa do passado, pois confiava na força da história pátria, acreditando que sendo, a todo o momento, lembrada e transmitida por gerações, aumentaria a estima da população, de modo a não deixar esmorecer o ânimo do povo português. Por isso, André, à beira da morte, esperava confiante o regresso do neto, pois acreditava que ele traria a notícia da descoberta da Índia. Desta forma, Luís era visto como o missionário do "Sol", ou seja, a força rejuvenescedora que traria a notícia do glorioso descobrimento que iluminaria o país, como é possível depreender da fala do velho, minutos antes de morrer, no momento do encontro com o neto que chegara da Índia: "Vem do Sol, que me aqueceu todo!... Ah! finalmente!... Luís, quando eu morrer cola os teus lábios aos meus e, no suspiro em que se for a minha alma, recolhe o beijo, a tua herança!" 
(CÂMARA, 2006, p.140) Assim, o jovem marinheiro representa a perpetuação do sonho imperial do avô.

Enquanto esperava o regresso heroico do neto, André consolava Teresica, de modo a não deixar desfalecerem-se suas esperanças: "Ao pé do tio revive a minha esperança, que os outros..." (CÂMARA, 2006, p.131). Teresica representa a juventude dividida entre a confiança e a descrença no futuro da nação, já "os outros" são aqueles que, contrapondo-se às expectativas de André, não acreditavam no retorno da esquadra de Vasco da Gama, representados, sobretudo, pela figura de Marta, viúva sofrida, para quem o mar só trouxe tristezas: "Tanta vez de luto encheram a nossa casa! Nas ondas nos ficaram o meu filho, o vosso, o meu homem... tantos! Já lá vão dois anos, mais de dois anos sem novas..." (CÂMARA, 2006, p.132). Desta forma, Marta representa os descrentes da predestinação da alma portuguesa e, principalmente, aqueles que não compactuavam com a esperança de um novo grande império calcado na África devido ao sacrifício dos homens portugueses e de suas famílias em proveito do sonho imperial dos dirigentes da Nação.

$\mathrm{Na}$ peça, essas duas linhas de pensamento são contrapostas por meio do uso da descrição temporal contrastante nos dois momentos. No início, quando Luís está em alto mar e seu destino é incerto, o autor cria um ambiente nebuloso, representado pela tempestade, símbolo da ameaça aos navegantes, que apavora as duas incrédulas mulheres: "Marta: Deus nos valha! Que tempo! ... ; Teresica: Toda a noite...! Não pude pregar o olho!...” (CÂMARA, 2006, p.127). Por sua vez, quando Luís retorna trazendo a grande notícia e recebendo o legado do avô, que, agora, pôde descansar em paz, a chuva aterrorizadora transforma-se em uma manhã de sol radiante, como é possível depreender pela rubrica informada pelo autor: "(o Sol brilha intensissimo. Luís aparece entre os umbrais)" e pela evocação do velho no momento de sua morte: "O Sol!... O Sol! ... Luís a tua boca!" (CÂMARA, 2006, p.140). Assim, as descrições temporais são utilizadas de modo a refletir as angústias, esperanças, confianças e alegrias presentes no interior de cada personagem. $\mathrm{O}$ sol intenso, presente no retorno do jovem navegador, representa uma tentativa de demonstrar confiança no destino imperialista do país, após período de intenso descredito representado pelo Ultimato (1890).

Com $O$ Beijo do Infante, principalmente por meio da figura do velho marinheiro, André, D. João da Câmara parece fazer um apelo ao povo português para que não se esqueça do seu passado, de quem são descendentes e confiem na predestinação do povo 
português, herdeiro das grandes descobertas, de modo a despertar no povo a esperança do ressurgimento do passado glorioso e torná-los fortes diante das turbulências enfrentadas no presente, como é possível evidenciar na crônica: "Sebastianistas fomos, sebastianistas seremos. É afinal uma maneira de levar a vida, que onde há esperança há maior paciência" (CÂMARA, 10 dez. 1903, p.266).

Essa atitude apresentada na peça fica mais explícita em suas crônicas. Em texto da revista $O$ Ocidente de 5 de janeiro de 1896, D. João exalta a pátria portuguesa e os soldados que voltavam vitoriosos da expedição à província ultramarina de Moçambique, após o feito heroico que prendeu o chefe Gungunhana, na província de Chaimite:

D'entro em pouco hão de chegar os nossos irmãos, os que foram para honra nossa, para bem da pátria, escrever com o próprio sangue, nas charnecas mortíferas da África, mais uma página gloriosa da história portuguesa. [...] São filhos dos heróis da Ásia os que hoje nos tétricos areais africanos enterraram a haste da bandeira das Quinas mais uma vez vitoriosa. Mais uma vez se pode exclamar o velho dito, aquele que nós todos dizemos, quanta vez rindo: - Ainda há portugueses! Que diferença entre a aurora desse janeiro e aquele sombrio crepúsculo de há cinco anos, quando o povo ia, ofendido, envergonhado, por essas ruas gritando em berros de dor, porque julgava ver a pátria a estorcer-se nas últimas agonias! Não, a pátria está viva! O ventre fecundo que produz tais filhos é o mesmo que deu vida e alma aos velhos heróis lusitanos, aos que se bateram nas serras contra romanos, nas planícies do Tejo e nos montes do Algarve contra mouros, em Aljubarrota contra as hostes do rei herege de Castela, por toda a Ásia contra o poderio imenso dos grandes imperadores do mundo. Foi aquela costa oriental da África que Luiz de Camões escolheu para cenário dos melhores cantos dos seus Lusíadas. [...] Mas a história não findou ainda, os capítulos gloriosos têm que engrossar o tomo. Por isso os portugueses lá voltaram [...]. (CÂMARA, 05 jan. 1896, p.2)

Em seu texto, D. João recorre à sensibilidade, à memória e à devoção patriótica e religiosa do leitor, pois, primeiramente, ressalta os perigos e as dificuldades que os soldados portugueses passaram em terras africanas para hastear a "Bandeira das Quinas". O uso da expressão "Bandeira das Quinas" e, mais adiante na crônica, de "Quinas Santas" em vez de "Bandeira Nacional" induz o leitor a lembrar da lenda da batalha de Ourique (1139), que prega a predestinação do povo português para a criação e consolidação de um império divino. Por conseguinte, ressalta o legado dos soldados do presente, mostrando que em suas veias corre a mesma coragem e o mesmo vigor dos seus antepassados heroicos, que combateram para a consolidação, defesa e expansão do território português. Para tanto, primeiro contrasta o momento atual com a época do Ultimato, que representou tempos de 
intensa agonia e desfalecimento do povo português e, em seguida, repassa os momentos da história portuguesa em que os lusitanos mostraram intensa bravura e amor à pátria, apontando os novos soldados como homens dignos da heroica ancestralidade que, mesmo passando por períodos de turbulência, ainda, vigora em suas almas. Por fim, o cronista enaltece a ação dos atuais soldados ao aludir que o grande feito do presente deve ser acrescentado ao livro das grandes conquistas, Os Lusíadas de Luís de Camões.

\section{O Neogarrettismo na peça Os Velhos e nas crônicas}

Outra forma encontrada para evadir-se da cruel realidade pela qual o país passava foi refugiar-se nos campos, onde ainda se mantinham as tradições portuguesas. Os autores, seguindo o exemplo do poeta romântico Almeida Garrett, voltam-se para o Portugal idílico, numa atitude de exaltação e valorização da paisagem natural, das pessoas simples, das tradições, crenças, festas e arte popular, dando origem a outra linha do Neorromantismo denominada Neogarrettismo. Esta nova corrente ganha força na década de 1890, após a publicação de sua teoria, defendida por Alberto d'Oliveira em Palavras Loucas (1894).

Os Neogarrettistas afirmam o gênio autóctone, defendendo uma literatura que rejeite as importações culturais na língua e costumes do país, afastando-se do cosmopolitismo e da corrupção dos centros urbanos em prol de uma vida simples e tranquila nas aldeias portuguesas, onde as tradições e a linguagem lusitana permanecessem autênticas, distantes das influências estrangeiras.

Os centros urbanos são vistos como opressores e sugadores da força humana, como atesta a personagem Jacinto, morador de Paris, do romance $A$ Cidade $e$ as Serras (1901), escrito por Eça de Queirós. A cidade de Lisboa, "becozinho da civilização" (CÂMARA, 06 jan. 1902, p.1), por sua vez, é vista apenas como uma instituição burocrática e administrativa, poluída, mórbida, agitada e suja, onde as riquezas e glórias do passado são substituídas por "banalidades cosmopolitas ridículas" (CÂMARA, 17 jul. 1902, p.1). Por sua vez, o campo é descrito de maneira idealizada e saudosa, como ambiente de alegria, saúde, tranquilidade, preservador e difusor das virtudes, dos costumes e da fé cristã, como comprova esta crônica, em que D. João descreve de maneira impressionista as festas e tradições ocorridas nas províncias, demonstrando seu encanto pelos costumes do campo e dando ao leitor a sensação de presenciar sua festividade e seus costumes:

É das províncias que chegam as melhores festas. [...] Falar de festas tradicionais e para tão longe, é com certeza ir acordar saudades. [...] Os 
dias de festas parecem que acordam com o sol mais dourado, [...] são cheios de luz e de perfumes. Dizem que povo se diverte a seu modo, como quiser, arme no sul as suas fogueiras em noites de São João, invente na Beira cantigas lindas que hão percorrer o país inteiro, junte-se no Minho para romarias que ainda são o que de mais belo podemos ver em Portugal, arme as igrejas nas ilhas para suas devoções ao Espírito Santo. (CÂMARA, 27, jul. 1903, p.2)

Em seu teatro, as características Neogarrettistas são evidenciadas em sua peça $O s$ Velhos. Representada pela primeira vez no teatro de D. Maria II, em 11 de março de 1893, a comédia, em três atos, passa-se durante os anos de 1878 e 1879 e tem por cenário a província de Santo Antônio das Areias, localizada nas charnecas alentejanas, onde a implantação da via ferroviária e as desapropriações que ela exige vêm perturbar o sossego dos pequenos proprietários rurais apegados à terra natal e às tradições passadas, em benefício do progresso, simbolizado pelo apito da locomotiva.

O primeiro ato inicia-se com a conversa dos velhos Pataca, Bento, Porfírio, e do Prior, a respeito da ameaça das expropriações das terras onde vivem. Diante da ameaça do progresso, "a tal máquina, a Besta do Apocalipse, a vomitar lume por esses campos agora tão quietinhos" (CÂMARA, 2006, p.169), a natureza árida da charneca transforma-se por meio da visão idealizada desses homens: a cerejeira produz "cereja que parecia um melão!" (CÂMARA, 2006, p.171), a vinha da Beirã, antes produtora de apenas "meio galão de pipa" (CÂMARA, 2006, p.171), torna-se um "bocadinho abençoado" (CÂMARA, 2006, p.171), que poderia vir a produzir "três pipas" de "vinho daqueles!" (CÂMARA, 2006, p.173), as terras sem cultivo, em pouso há três anos, transformam-se em terras muito produtivas, que poderiam vir a dar "quatorze sementes" e tornar-se um farto "centeio" (CÂMARA, 2006, p.171). Tais exageros demonstram o apreço desses camponeses por suas propriedades: "Guerra de morte aos salteadores das nossas terras, do chão abençoado que herdamos de nossos pais!” (CÂMARA, 2006, p.173). Da conversa empreendida entre os velhos, sobressaem, também, o poder acolhedor e fortalecedor exercido pela natureza desses campos sobre seus homens, pois Pataca lembra que, quando perdeu a filha, foi no trabalho exercido nessas terras que encontrou consolo e ânimo para dar prosseguimento à sua vida e sustentar a neta: "Peguei a enxada e fui por esses campos, até lá abaixo ao Server, desviar as águas. [...] Eu chorava a minha filha regando a minha horta. Nessa hora de angústia fui trabalhar na terra... porque a terra é nossa mãe” (CÂMARA, 2006, p.166). 


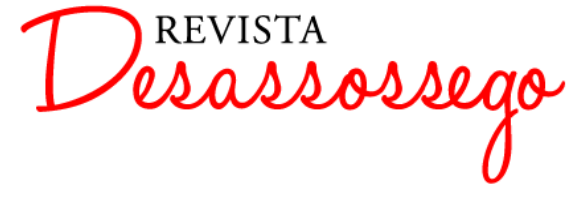

DESASSOSSEGO 12 | DEZ/2014 | ISSN 2175-3180

DOI: http://dx.doi.org/10.11606/issn.2175-3180.v6i12p81-94

A esse grupo envelhecido em meio à vida rústica e tradicional vem juntar-se Júlio, engenheiro de vinte e sete anos, mensageiro do progresso: "Nossa bandeira trazemos escrita uma divisa: - Progresso! Hastear esse pendão em plena charneca do Alentejo é missão que muito nos honra e que o Alentejo nos devia agradecer!" (CÂMARA, 2006, p.174). O jovem, a princípio recebido pelos camponeses como "pedreiro livre", "homem de ciência, mas sem consciência" (CÂMARA, 2006, p.164), acaba por agradar os velhos devido à sua inteligência e artimanha, aliadas ao seu carisma: "Desejo falar com as pessoas mais importantes dessa aldeia” (CÂMARA, 2006, p.174). Desta forma, Júlio, representante do progresso, cativa a todos, menos ao velho Prior, símbolo dos valores conservadores.

A peça apresenta o confronto entre a tradição e a modernidade. De um lado o Prior, guardião implacável dos costumes e heranças antigas, que se pressente ameaçado pela chegada do comboio: "E que são vosmecês vindo aqui roubar-nos o sossego com os seus óculos, picaretas e dinamites? Começaram por roubar terra, e como se não fosse o bastante... já são três pequenas da aldeia casaram com malteses" (CÂMARA, 2006, p.204). A chegada da locomotiva representa não apenas a perda da terra, mas, também, da autenticidade do modo de ser campesino. Para ele, como ressalta Pimentel (1981, p.91), "mais do que uma união de amor, o amor deve ser uma união totalizante, só possível pela junção de duas metades, que desabrochem num mesmo contexto social, corrente dos seus preconceitos, ideais e hábitos". Por isso, o religioso não aceita o amor entre Emilinha e Júlio e tenta a todo custo separar o casal: "Somos velhos, somos agarrados a estas tradições. Queremos ver as filhas da nossa aldeia casadas aqui com quem lhes saiba amanhar as terras, com quem lhes traga um bocadinho de chão, que se possa deitar uns muros abaixo, arredondar um pedaço de vinha" (CÂMARA, 2006, p.219).

Por outro lado, há a figura de Júlio, jovem de Lisboa, que representa o progresso e a suposta evolução da cultura portuguesa. No entanto, tal confronto não se sustenta, pois, como bem nota Pimentel (2003, p.200), o jovem do caminho de ferro, leitor de umas "histórias de aldeias muito simples", escritas por Júlio Dinis, "será absorvido pelo universo rural com o qual tinha estreita afinidade." O engenheiro entrega-se aos encantos da gente do povo, à música, às quadras populares, à comida e, principalmente, à beleza das camponesas, representadas por Emilinha, jovem de dezenove anos, cabelos pretos, prendada e temente a Deus, ou seja, típica representante dos valores femininos do campo. 


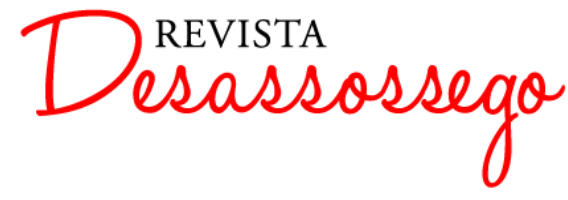

DESASSOSSEGO 12 | DEZ/2014 | ISSN 2175-3180

DOI: http://dx.doi.org/10.11606/issn.2175-3180.v6i12p81-94

Ao se casar com Emilinha, Júlio, homem do caminho de ferro, aceita, sem contestar, o legado do amor dos avós da jovem, Patacas e Emília, que comemoram bodas de ouro fazendo-se reproduzir a vida rústica deles. Assim, com a neta encaminhada, os velhos sentem-se preparados para o descanso eterno, pois sabem que a felicidade do seu amor e o afeto que sentem pela terra será revivido na figura do jovem casal; no jantar de comemoração de cinquenta anos da feliz união, Pataca expõe seu sentimento:

Como então parece que foi ontem! Aqui estou outra vez entre os meus melhores amigos! Lá fora os campos produzem como antes, o vinho tem o mesmo sabor, o mesmo sabor o pão! Saio de casa, da mesma casa de onde saí no dia ao do casamento, e vejo os mesmos penedos, o mesmo castelo de Marvão, os montes de Espanha ao longe, como vejo as mesmas estrelas no céu! Nada mudou! Somos sempre os mesmos, agarrados ao mesmo cantinho da terra, como o foram os nossos pais, como hão de ser os nossos filhos ... como há de ser a nossa neta. Nada mudou! (CÂMARA, 2006, p.247)

Todavia, como bem percebe Emília, “os tempos correm! Os tempos são outros!” (CÂMARA, 2006, p.253). O discurso do velho Pataca é interceptado pelo apito prolongado do comboio, símbolo do progresso. Disso depreende-se que Júlio compartilha com os velhos da beleza e amor à vida do campo, porém, adaptado às novas situações sociais do país, representada pelo silvo da locomotiva que toca todas as vezes que Pataca insiste em reafirmar que os tempos e as coisas, ainda, são as mesmas e que nada mudou.

Em Os Velhos, D. João da Câmara, descendente da aristocracia, portanto educado segundo seus padrões tradicionais, e formado em engenharia pela Politécnica de Lisboa, consegue aliar o elogio à tradição e aos costumes campesinos à modernidade exigida pelas novas estruturas socioeconômicas portuguesas, mostrando, como bom homem do seu tempo, que é possível desfrutar das vantagens da modernidade sem abrir mão das tradições, pois, como ele mesmo ressalta em sua crônica, onde demonstra ser grande defensor das tradições de seu país: "conservar as tradições nunca foi não progredir. Deixem as raízes em boa terra e melhores frutos hão de colher-se na árvore. Nunca será por amarmos demais as nossas glórias que havemos de quedar parados e ver caminhando os mais" (CÂMARA, 17 jul. 1905, p.1).

\section{Considerações Finais:}

Desta forma, D. João da Câmara, por meio de suas crônicas e do seu teatro, apresenta caminhos diferentes de um destino comum: o viés simbolista/ decadentista desenvolvido nas peças $O$ Pântano, o romantismo idealista de exaltação e fé nas glórias 


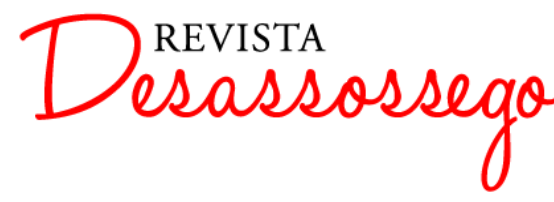

DESASSOSSEGO 12 | DEZ/2014 | ISSN 2175-3180

DOI: http://dx.doi.org/10.11606/issn.2175-3180.v6i12p81-94

portuguesas, explícitos no $O$ Beijo do Infante, e a romântica defesa das tradições portuguesas evidenciadas em $O s$ Velhos corroboram com o sentimento que pairava sobre a intelectualidade portuguesa do final do século XIX. Este sentimento iniciou-se por desprezar a sociedade em busca de uma arte pura, de alto valor estético, passou a abandonar a razão e o culto da civilização, buscando na natureza, no povo português e na exaltação saudosa dos feitos históricos da pátria, um refúgio contra as nódoas do presente e uma maneira de reagir em prol de um futuro desesperançoso. A literatura simbolista, assim como as manifestações neorromânticas que assolaram a sociedade portuguesa da época, consiste numa maneira do intelectual português se expressar contra os males impostos pela sociedade imperialista e capitalista daquele momento, conforme demonstrado nas crônicas e no teatro de D. João da Câmara.

\section{Referências Bibliográficas}

AMORA, Antônio Soares. Presença da Literatura Portuguesa. Simbolismo, v. VI. São Paulo: Difusão Europa, 1969.

BALAKIAN, O Simbolismo. Trad. José Bonifácio Caldas. São Paulo: Perspectiva, 1967.

CÂMARA, D. João da. "Crônica Ocidental." O Ocidente: Revista Ilustrada de Portugal e do Estrangeiro , no 613. Lisboa, 5 jan. 1896. p.2, 1 col.

. "Crônica Ocidental." O Ocidente: Revista Ilustrada de Portugal e do Estrangeiro , no 613.

Lisboa, 10 dez. 1903. p.2, 1 col.

. "Crônica Ocidental". O Ocidente: Revista Ilustrada de Portugal e do Estrangeiro, n ${ }^{\circ}$ 898,

Lisboa, 10 dez. 1903. p.266, 2 col.

"Aniversário Triste". Gazeta de Notícias, 09 dez. 1901, p.1, 1 col.

"A Cidade e as Serras". Gazeta de Notícias, 06 jan. 1902. p.1, 1 col.

. "Outono". Gazeta de Notícias, 10 nov. 1902, p.1, 8 col.

"Mil Trovas". Gazeta de Notícias, 27 jul. 1903, p.1, 8 col.

"Saudade e Melancolia". Gazeta de Notícias, 31 ago. 1903, p.3, - 5 col.

"Os pretos de São Jorge". Gazeta de Notícias, 17, jul. 1905, p.1, 1 col.

O Pântano. In: _. Teatro Completo. MARTINS, Rita (org. e intr.) v. II Lisboa:

Imprensa Nacional - Casa da Moeda, 2006.

"Os Velhos" e "O Beijo do Infante". In:

v. II. Lisboa: Imprensa Nacional Casa da Moeda, 2006.

PEREIRA, José Carlos Seabra. Decadentismo e Simbolismo na Poesia Portuguesa. Coimbra: Centro de Estudos Românicos 1975.

PIMENTEL Jorge F. Vieira. Tendências da Literatura Dramática no final do século XIX: D. João da Câmara, um caso exemplar. Ponta Delgada: Universidade dos Açores, 1981.

Fulgor e limitações da literatura dramática (1886-1904). In: CASTRO, Francisco L.

História da literatura portuguesa: do simbolismo ao modernismo. v. 6. Lisboa: Alfa, 2003. p.187205.

REBELLO, Luiz Francisco. D. João Gonçalves Zarco da Câmara. In: SIMÕES, João Gaspar (dir.). Perspectiva da Literatura Portuguesa do século XIX.Lisboa: Ática, 1948. p.287 - 311.

. "D. João da Câmara e o Teatro Português finissecular". In: . Fragmentos de uma dramaturgia. Lisboa: Casa da Moeda, 1994. p.34 - 48. 